\title{
ANALISIS MINAT DAN MOTIVASI BERWIRAUSAHA MAHASISWA DI UNIVERSITAS DIRGANTARA MARSEKAL SURYADARMA (UNSURYA) (Studi pada Mahasiswa Mata Kuliah Manajemen Bisnis Ritel, Kelas Reguler Pagi, Program Studi Akuntansi dan Manajemen Semester 4 Tahun Ajaran 2016/2017)
}

\author{
Sari Nalurita \\ sari.nalurita10@apps.ipb.ac.id
}

\begin{abstract}
This research aims to 1) Know Entrepreneurship Motivation of Unsurya's Students and 2) Knowing the interest of Unsurya's students in entrepreneurship. The method of this research was used qualitative research with descriptive approach, using primary data in the academic year of 2016/2017. Researcher took the regular Retailing Business Management class semesters 4 as the population with 14 students as the sample and taken by random sampling. The results showed that the average motivation of Unsurya's students in entrepreneurship was 66.51 percent with the greatest motivation value is the ambition for freedom indicator that is equal to 75.71 percent, while the self realization value is 48.81 percent, while the pushing factor with a value of 75 percent. Analysis of Unsurya's students interest in entrepreneurship is equal to 42,86 percent, while uninterested is 28,57 percent and still considering 28,57 percent. This shows that the interest of Unsurya students to the entrepreneur is significant.
\end{abstract}

\section{Keywords: Entrepreneurial Intention, Entrepreneurial Motivation, Entrepreneurship, Student}

\section{ABSTRAK}

Penelitian ini bertujuan untuk 1) Mengetahui Motivasi Berwirausaha Mahasiswa Unsurya dan 2) Mengetahui minat berwirausaha mahasiswa Unsurya. Metode yang digunakan adalah penelitian kualitatif dengan pendekatan deskriptif, menggunakan data primer pada Tahun Ajaran 2016/2017 dengan populasi mahasiswa mata kuliah manajemen bisnis ritel kelas reguler pagi semester 4 dan sampel sebanyak 14 orang yang diambil secara random. Hasil penelitian menunjukkan bahwa motivasi rata-rata mahasiswa Unsurya dalam berwirausaha adalah sebesar 66,51 persen dengan nilai motivasi terbesar adalah pada indikator ambition for freedom yaitu sebesar 75,71 persen, sedangkan nilai self realization 48,81 persen, sedangkan pushing factor dengan nilai sebesar 75 persen. Analisis minat mahasiswa Unsurya dalam berwirausaha adalah sebesar 42,86 persen, sedangkan yang tidak berminat sebanyak 28,57 persen dan yang masih mempertimbangkan sebanyak 28,57 persen. Hal ini menunjukkan bahwa minat mahasiswa Unsurya terhadap wirausaha adalah cukup besar.

\section{Kata kunci : motivasi, minat, analisis minat, kewirausahaan}

\section{PENDAHULUAN}

Kewirausahaan adalah salah satu solusi mengatasi pengangguran. Kegiatan usaha atau bisnis akan mampu mendorong laju pertumbuhan ekonomi suatu negara dan menyerap tenaga kerja sehingga angka pengangguran bisa ditekan.

Saat ini kemajuan bidang ilmu pengetahuan dan teknologi semakin berkembang. Termasuk dalam bidang usaha, munculnya e-commerce menjadi salah satu faktor yang bisa dimanfaatkan untuk berusaha dengan mudah dan efisien. Sumardi (2007) menjelaskan bahwa pengusaha atau wirausahawan (entrepreneur) merupakan seorang yang menciptakan sebuah usaha atau bisnis yang diharapkan dengan risiko dan ketidakpastian untuk memperoleh keuntungan 
dan mengembangkan bisnis dengan cara membuka kesempatan.

Di era yang kompetitif ini, mahasiswa diharapkan lulus sebagai cendekia sekaligus wirausahawan. Berbagai disiplin ilmu dalam rumpun ekonomi, pada akhirnya adalah bertujuan agar kita mampu mengembangkan jiwa kewirausahaan.

Peranan Perguruan Tinggi dalam mengembangkan minat berwirausaha dan menggali faktor yang berpengaruh pada perilaku berwirausaha sangat penting. Minat berwirausaha akan menjadikan seseorang untuk lebih giat mencari dan memanfaatkan peluang usaha dengan mengoptimalkan potensi yang dimiliki.

Penumbuhan jiwa wirausaha didapat dalam berbagai hal dan tempat. Salah satunya adalah di Institusi Pendidikan. Dewasa ini Perguruan Tinggi memasukkan berbagai mata kuliah yang erat hubungannya dengan kewirausahaan, selain mata kuliah kewirausahaan itu sendiri. Harapannya dengan adanya mata kuliah ini dapat meningkatkan kemampuan soft skill dan pola pikir mahasiswa. Pendidikan kewirausahaan yang ditanamkan salah satunya di mata kuliah Manajemen Bisnis Ritel, adalah salah satu cara untuk memperkenalkan bagaimana berwirausaha dalam tingkat eceran.

Pendidikan yang diberikan tidak hanya dengan metode caramah berupa teori namun juga praktek bisnis dalam bidang ritel. Sehingga mahasiswa diharapkan dapat mengaplikasikan teori yang didapat ke dalam praktek bisnis nyata yang sesuai dengan kondisi pasar sebenarnya. Penggunaan ecommerce menjadi alat bagi mahasiswa untuk melakukan bisnis ritel skala kecil dibantu dengan penggunaan sosial media. Bisnis termudah yang bisa dilakukan di kalangan mahasiswa tentunya bisnis dengan modal kecil atau bahkan tanpa modal awal. Mereka dapat memanfaatkan e-commerce sebagai retailer sehingga tidak memerlukan modal awal untuk produksi atau penyediaan barang. Mahasiswa bisa menggunakan sistem pemesanan online dengan biaya pesanan yang ditanggung oleh pembeli, dengan cara pembeli mentransfer sejumlah uang senilai harga barang di tambah fee yang di harapkan mahasiswa dan ongkos kirim, setelah itu mahasiswa dapat melakukan pemesanan online ke toko online yang menjual berbagai produk ritel. Mahasiswa tidak memerlukan toko, gudang, bahkan biaya produksi. Hal ini sangat memungkinkan bagi pebisnis pemula untuk berwirausaha dengan modal minimal dan resiko minimal. Sedangkan keuntungan tetap dapat diperoleh dari besarnya margin harga produk dari harga yang ditawarkan toko online ke harga yang dijual mahasiswa ke konsumen akhir.

Antusias mahasiswa untuk mengaplikasikan teori kepada praktek nyata berbisnis ritel diharapkan dapat menumbuhkan jiwa kewirausahaan. Namun dalam hal ini diperlukannya motivasi dan minat mahasiswa terhadap kewirausahaan.

Minat tidak dibawa sejak lahir tetapi tumbuh dan berkembang sesuai dengan faktor- 
faktor yang mempengaruhinya. Minat berwirausaha dipengaruhi oleh berbagai hal, salah satunya motivasi. Minat berwirausaha akan menjadikan seseorang untuk lebih giat mencari dan memanfaatkan peluang usaha dengan mengoptimalkan potensi yang dimiliki. Minat adalah kecenderungan yang menetap untuk memperhatikan aktivitas (Djamarah, 2011).

Minat sangat dibutuhkan bagi mahasiswa yang berwirausaha agar mampu mengidentifikasi peluang usaha, kemudian mendayagunakan peluang usaha untuk menciptakan peluang kerja baru. Minat setiap mahasiswa untuk berwirausaha tentunya akan berbeda-beda. Minat tidak dibawa sejak lahir tetapi tumbuh dan berkembang sesuai dengan faktor-faktor yang mempengaruhinya. Minat berwirausaha dipengaruhi oleh berbagai hal, salah satunya motivasi. Motivasi merupakan faktor penting untuk meningkatkan minat mahasiswa dalam berwirausaha. Sedangkan indikator minat belajar dapat diukur melalui 4 indikator sebagaimana yang disebutkan oleh (Slameto, 2010) yaitu ketertarikan untuk belajar, perhatian dalam belajar, motivasi belajar dan pengetahuan.

\section{TUJUAN PENELITIAN}

Berdasarkan latar belakang, maka penelitian ini mempunyai tujuan untuk mengetahui 1) motivasi kewirausahaan

Waktu penelitian adalah bulan April 2017 dengan menggunakan angket dengan responden seluruh sampel menggunakan alat mahasiswa Unsurya kelas reguler pagi pada mata kuliah manajemen bisnis ritel, dan 2) minat berwirausaha mahasiswa Unsurya kelas reguler pagi mata kuliah manajemen bisnis ritel.

\section{METODOLOGI PENELITIAN Jenis Penelitian}

Penelitian yang dilakukan adalah penelitian dengan metode kualitatif dengan pendekatan deskriptif, yaitu dengan menggambarkan minat dan motivasi mahasiswa dalam kewirausahaan jenis ritel (tingkat eceran).

\section{Populasi dan Sampel}

Populasi dalam penelitian ini adalah seluruh mahasiswa regular pagi semester empat (4) yang mengambil mata kuliah Manajemen Bisnis Ritel tahun ajaran 2016/2017 di Unsurya yaitu 28 mahasiswa. Sampel diambil sebanyak 14 mahasiswa di ambil secara random sebanyak 50 persen dari total populasi.

\section{Sumber Data, Waktu Penelitian dan Alat} Analisis

Penelitian ini menggunakan data primer yang berasal dari jawab responden dengan menggunakan angket yang berisi sejumlah pertanyaan yang sudah di beri bobot seputar motovasi dan minat kewirausahaan. Pertanyaan berupa data yang berkaitan dengan variabel bebas dan terikat (minat dan motivasi) dengan 14 butir pertanyaan.

bantu Mc. Excel untuk pengolahan data. Berikut ini adalah kisi-kisi pengisian angket 
Tabel 1

Kisi-kisi Angket Motivasi Kewirausahaan Mahasiswa Unsurya, 2017

\begin{tabular}{|l|c|c|}
\hline \multicolumn{1}{|c|}{ Indikator Motivasi } & Banyak butir indikasi & Butir Pertanyaan \\
\hline Ambition for freedom & 5 & A,B,C,D,E \\
\hline Self-realisation & 6 & F,G,H,I,J,K \\
\hline Pushing factors & 2 & L,M \\
\hline Jumlah & 13 & 13 \\
\hline
\end{tabular}

Sumber : Data diolah

\section{Variabel Penelitian}

Variabel penelitian adalah suatu atribut atau sifat atau nilai dari orang, obyek, atau kegiatan yang mempunyai variasi tertentu yang ditetapkan oleh peneliti untuk dipelajari dan kemudian ditarik kesimpulannya (Sugiyono, 2008). Variabel-variabel penelitian yang digunakan dalam penelitian ini adalah minat menjadi wirausaha yang merupakan variabel terikat (Y) dan motivasi menjadi wirausaha sebagai variabel bebasnya $(\mathrm{X})$.

Adapun yang menjadi indikator motivasi yaitu 1) Ambition for freedom, 2) Selfrealisation, dan 3) Pushing factors. Indikator Ambition for freedom: aktivitas lebih bebas, memiliki usaha sendiri, menjadi lebih dihormati, terdepan dalam menerapkan ide baru, mengembangkan hobi dalam bisnis. Indikator Self-realisation: memperoleh posisi yang lebih baik di masyarakat, merasakan tantangan, motivasi dan memimpin orang lain, melanjutkan tradisi keluarga, mengimplementasikan ide atau berinovasi, mengikuti orang lain, minat dan motivasi berwirausaha. Indikator Pushing factors : kehilangan pekerjaan dan memperoleh
$\mathrm{Y}=$ Minat Berwirausaha

$\mathrm{X}=$ Motivasi Berwirausaha

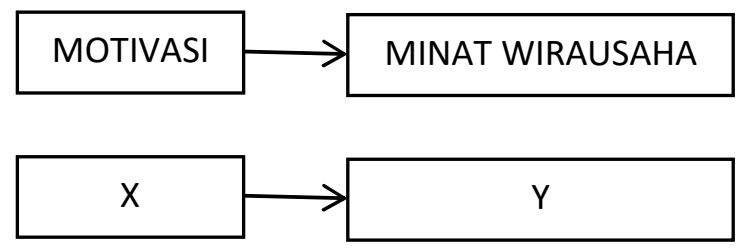

Gambar 1. Kerangka Pikir

pendapatan yang lebih baik. Seluruh variable motivasi ini berjumlah 13 indikator yang kemudian di masukkan kedalam pertanyaan 13 butir pertanyaan dengan jawaban yang terdiri dari Ya atau Tidak. Masing-masing pertanyaan jika jawabannya Ya maka diberi skor 4 dan jika Tidak maka diberi skor 5.

Pada variabel minat berwirausaha akan dibagi dalam skala kategori yang terdiri dari: 1) Berminat wirausaha 2) Dalam pertimbangan untuk wirausaha, 3) Tidak berminat wirausaha. Kemudian di hitung persentasenya dari total sampel.

\section{Teknik Analisis Data}

Minat Berwirausaha 
Venesaar et al. (2006) dalam penelitian yang berjudul Student's Attitudes and Intentions toward Entrepreneurship at Tallinn University of Technology (2006:103) membagi minat berwirausaha ke dalam empat kategori, yaitu:

1. Belum berminat menjadi wirausaha.

2. Sudah berminat, tetapi belum memulai.

3. Sudah memiliki dan menjalankan sebuah usaha.

4. Sudah pernah memiliki usaha sebelumnya, tetapi gagal.

Sedangkan dalam penelitian ini minat mahasiswa diukur melalui tiga kategori pertanyaan pilihan yaitu :

1. Berminat terhadap kewirausahaan

2. Dalam pertimbangan

3. Tidak berminat terhadap kewirausahaan.

Setiap kategori di jumlah dan dirataratakan setelah itu dihitung persentasinya terhadap jumlah sampel (perbandingan dengan nilai rata-rata pada masing-masing kategori minat). Setiap mahasiswa hanya berhak memilih satu kategori yaitu apakah kategori satu, dua atau tiga.

Dalam penelitian ini, data yang diperoleh merupakan hasil dari pengamatan, observasi, dan penelaahan dokumen. Kemudian data tersebut dianalisis dengan menggunakan kata-kata yang biasanya disusun ke dalam teks yang diperluas.

\section{Motivasi Berwirausaha}

Motivasi berwirausaha didefinisikan sebagai sesuatu yang melatarbelakangi atau mendorong seseorang melakukan aktivitas dan memberi energi yang mengarah pada pencapaian kebutuhan, memberi kepuasan ataupun mengurangi ketidakseimbangan dengan membuka suatu usaha atau bisnis (Zimmerer dalam Budiati, 2012).

Variabel motivasi menggunakan data kualititatif yang diukur dengan skala Likert. Hasil analisis ini akan dijabarkan dalam bentuk analisis diskriptif, sehingga akan memberikan penjelasan mengenai berbagai karakteristik minat yang ditinjau dari aspek motivasi, kepribadian dan karakteristik lain.

Venesaar et al. (2006:104) menjelaskan bahwa motivasi seseorang menjadi wirausaha dibagi dalam tiga dimensi, yaitu Ambition for freedom (Ambisi kemandirian), Self-realisation (Realisasi diri), Pushing factors (Faktor pendorong). Berikut dimensi motivasi beserta indikatornya:

1. Ambition for freedom (Ambisi kemandirian)
a. Aktivitas lebih bebas
b. Memiliki usaha sendiri
c. Menjadi lebih dihormati
d. Terdepan dalam menerapkan ide baru
e. Mengembangkan hobi dalam bisnis

2. Self-realisation (Realisasi diri)
a. Memperoleh posisi yang lebih baik di masyarakat
b. Merasakan tantangan
c. Memotivasi dan memimpin orang lain 
d. Melanjutkan tradisi keluarga

e. Mengimplementasikan ide atau berinovasi

f. Mengikuti orang lain

3. Pushing factors (Faktor pendorong)

a. Kehilangan pekerjaan

b. Memperoleh pendapatan yang lebih baik

c. Tidak puas dengan pekerjaan

Setelah angket yang berisi 13 butir pertanyaan diperoleh, kemudian di analisis

Tabel 2.

Nilai Jawaban dari Indikator Motivasi

\begin{tabular}{|c|c|}
\hline Jenis Jawaban & Nilai \\
\hline Ya & 4 \\
\hline Tidak & 5 \\
\hline
\end{tabular}

Sumber : Data diolah

Selanjutnya menganalisis motivasi berwirausaha mahasiswa adalah dengan menjumlah semua nilai masing-masing butir pertanyaan yaitu sebanyak 13 pertanyaan dari 14 responden, kemudian dilihat manakah yang memberikan konstribusi terbesar kemudian di rata-ratakan dan di persentasikan. Rata-rata persentasi terbesar menunjukkan motivasi yang paling signifikan mempengaruhi minat siswa terhadap kewirausahaan.

Didalam memberikan respon terhadap pernyataan, responden diminta memberikan tanggapan yang paling sesuai dengan apa yang dirasakan.

Secara garis besar kerangka pemikiran dalam penelitian ini dapat dilihat dalam dengan pemberian nilai (skor) untuk tiap-tiap jawaban. Jawaban terdiri dari Ya atau Tidak. Pertanyaan yang diberikan kepada responden dengan menggunakan alat ukur skala Likert. Jawaban Ya bernilai 4 dan jawaban Tidak bernilai 5 .

Dalam penelitian ini dilakukan analisis dengan tabulasi silang pembeda kategori pada beberapa karakteristik minat terhadap motivasi responden.

Gambar 2.

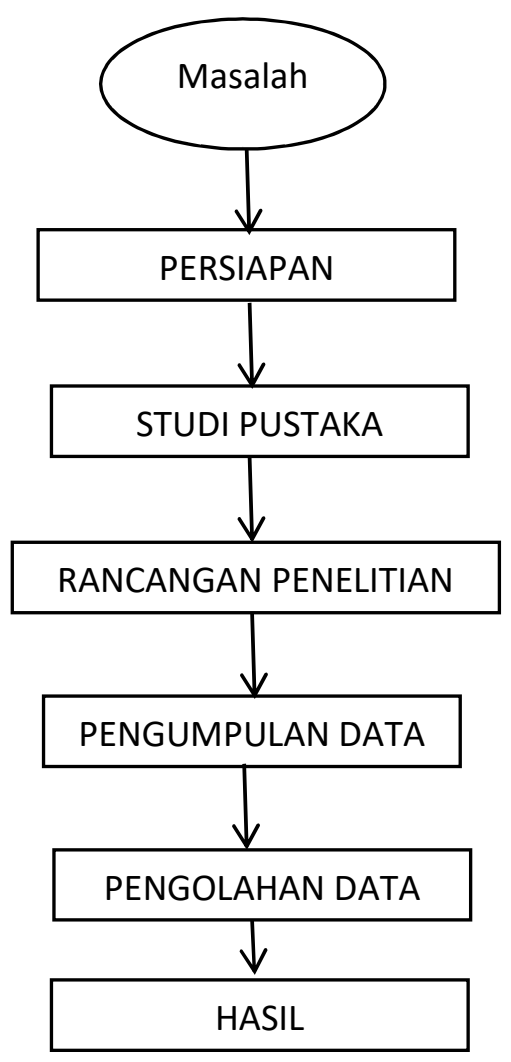

Kerangka Pemikiran

Penelitian berangkat dari masalah minat dan motivasi mahasiswa, persiapan, yaitu membagi mahasiswa kedalam beberapa kelompok retel, dimana mahasiswa bebas 
menentukan produk yang akan di jual, metode penetapan harga dan promosi, mahasiswa wajib mempresentasikan hasil penjualannya sekali dalam seminggu yaitu saat perkuliahan, berapa nilai penjualan dan kendala-kendala yang dihadapi selama berjualan. Proses selanjutnya adalah studi pustaka, dimana peneliti sekaligus dosen pengampu mata kuliah manajemen bisnis ritel mengadakan studi pustaka, mengumpulkan semua literature yang berkaitan dengan kewirausahaan ritel khususnya mengenai minat dan motivasi berwirausaha. Tahap selanjutnya adalah membuat rancangan penelitian, seperti menentukan tujuan penelitian yang bersumber dari masalah yang dihadapi dalam kewirausahaan, jumlah sample, jenis data, metode penelitian, alat analisis dan waktu penelitian. Selanjutnya peneliti mengumpulkan data primer berupa angket yang berisi 13 butir pertanyaan. Tahap selanjutnya adalah pengolahan data, yang kemudian di analisis untuk memperoleh hasil.

\section{HASIL DAN PEMBAHASAN}

\section{Analisis Motivasi}

Tabel 3 menjelaskan bagaimana persepsi mahasiswa kelas reguler mata kuliah Manajemen Bisnis Ritel terhadap minat berwirausaha. Berdasarkan hasil penelitian yang dilakukan pada 14 mahasiswa, diperoleh hasil bahwa ambition for freedom atau ambisi untuk kemandirian merupakan motivasi terbesar mahasiswa Unsurya untuk berwirausaha yaitu rata-rata sebesar 75,71 persen dan indikator terbesar adalah keinginan untuk di hormati, 100 persen mahasiswa menjawab Ya bahwa mereka meyakini dengan berusaha mandiri maka mereka akan lebih dihormati. Hal ini menjelaskan bahwa motivasi terbesar mahasiswa Unsurya adalah rasa keinginan untuk kebebasan, baik kebebasan memperoleh pendapatan secara mandiri, maupun kebebasan dalam hal kemandirian finansial, dan indikator yang memotivasinya adalah dengan kemandirian secara finansial mereka akan lebih dihormati oleh masyarakat. Hasil penelitian mengenai motivasi mahasiswa terdapat pada Tabel 3. 
Tabel 3.

Analisis Motivasi Kewirausahaan

\begin{tabular}{|c|l|c|c|c|c|c|}
\hline Indikator & \multicolumn{1}{|c|}{$\begin{array}{c}\text { Butir } \\
\text { Pertanyaan }\end{array}$} & $\begin{array}{c}\text { Ya } \\
\text { (orang) }\end{array}$ & $\begin{array}{c}\text { Tidak } \\
\text { (orang) }\end{array}$ & $\begin{array}{c}\text { Jumlah } \\
\text { (orang) }\end{array}$ & $\begin{array}{c}\text { Persentase } \\
(\%)\end{array}$ & $\begin{array}{c}\text { Rata-rata } \\
(\%)\end{array}$ \\
\hline $\begin{array}{c}\text { Pushing } \\
\text { Factor }\end{array}$ & Pertanyaan A & 10 & 4 & 14 & 71.43 & $\mathbf{7 5 , 0 0}$ \\
\hline Ambition for \\
freedom
\end{tabular}

Sumber : Data diolah

Sementara itu pushing factor atau adanya faktor yang menekan untuk mereka berwirausaha menempati urutan ke dua setelah ambition for freedom dengan ratarata sebesar 75 persen, dengan indikator motivasi terbesar adalah kehilangan pekerjaan sebesar 78,57 persen. Hal ini menunjukkan bahwa mahasiswa Unsurya jika mereka kehilangan pekerjaan, akan memotivasi mereka untuk berwirausaha. Hal ini menunjukkan bahwa faktor yang menekan mereka untuk berwirausaha menjadi faktor signifikan kedua yang mempengaruhi motivasi mahasiswa dalam berwirausaha terutama terutama karena hal kehilangan pekerjaan.

Sedangkan self realization atau realisasi diri hanya memperoleh rata-rata sebesar 48,81 persen dengan motivasi terbesar adalah dengan berwirausaha diyakini akan memperoleh posisi yang baik di masyarakat sebesar 71,43 persen. Kesimpulan mengenai analisis motivasi dapat dilihat pada Tabel 4. 
Tabel 4.

Ringkasan Analisis Motivasi

\begin{tabular}{|l|c|}
\hline \multicolumn{1}{|c|}{ Indikator Motivasi } & $\begin{array}{c}\text { Persentase } \\
(\%)\end{array}$ \\
\hline Ambition for freedom (ambisi untuk kebebasan) & 75,71 \\
\hline Pushing factors (faktor tekanan) & 75,00 \\
\hline Self-realisation (realisasi diri) & 48,81 \\
\hline
\end{tabular}

Sumber : Data Diolah

\section{Analisis Minat}

Data dikumpulkan menggunakan angket untuk meminta jawaban tentang minat mahasiswa. Angket tersebut diberikan kepada
14 orang mahasiswa yang diambil secara random kemudian dilakukan pengolahan dan rekapitulasi data. Hasil analisis minat dapat dilihat pada Tabel 5.

Tabel 5

Hasil Minat Mahasiwa terhadap Kewirausahaan

\begin{tabular}{|l|c|c|}
\hline \multicolumn{1}{|c|}{ Indikator Minat } & $\begin{array}{c}\text { Jumlah } \\
\text { (orang) }\end{array}$ & $\begin{array}{c}\text { Persentase } \\
\text { (\%) }\end{array}$ \\
\hline Berminat & 6 & 42,86 \\
\hline Dalam Pertimbangan & 4 & 28,57 \\
\hline Tidak Berminat & 4 & 28,57 \\
\hline Total & 14 & 100 \\
\hline
\end{tabular}

Sumber : Data Diolah

Berdasarkan angket yang disebar

kepada sejumlah responden, maka diketahui hasil analisis minat mahasiswa pada Tabel 5. di atas, analisis minat diketahui bahwa minat mahasiswa Unsurya terhadap wirausaha adalah sebanyak enam (6) orang responden menyatakan berminat terhadap wirausaha atau sebanyak 42,86 persen dari total responden. Nilai ini cukup besar, dan menunjukkan bahwa mahasiswa Unsurnya memiliki ketertarikan untuk berwirausaha mandiri.

Sementara yang membutuhkan pertimbangan untuk berwirausaha mandiri sebanyak empat (4) orang atau sebanyak 8,57 persen dari total responden, sama banyaknya dengan mahasiswa yang tidak berminat terhadap kewirausahaan sebesar 28,57 persen. Hal ini artinya, ada potensi untuk mengarahkan 28,57 persen mahasiswa yang masih dalam pertimbangan untuk pada akhirnya berminat terhadap wirausaha.

Rangsangan untuk menumbuhkan minta kewirausahaan dapat dilakukan dengan berbagai cara, namun hal ini membutuhkan penelitian lebih lanjut. Secara general dapat dijelaskan bahwa mahasiswa Unsurya memiliki minat yang sedang terhadap wirausaha dengan potensi minat yang cukup signifikan. 


\section{KESIMPULAN}

1. Berdasarkan analisis motivasi diketahui bahwa mahasiswa termotivasi dari indikator ambition for freedom artinya keinginan mereka untuk mandiri sangat memotivasi mereka untuk menjadi wirausahawan yaitu sebesar 75,71 persen dengan lebih spesifik lagi adalah indikator agar dihormati di lingkungan masyarakat yang memperoleh nilai sebesar 100 persen. Sementara itu indikator pushing factor atau faktor karena adanya tekanan menempati urutan ke dua sebagai faktor yang memotivasi mahasiswa dalam berwirausaha yaitu sebesar 75 persen dengan indikator terbesar adalah kehilangan pekerjaan dengan nilai sebesar 100 persen. Dan indikator terakhir yang memotivasi mahasiswa adalah self realization atau realisasi diri dengan nilai sebesar 48,81 dengan indikator terbesarnya adalah dengan berwirausaha akan memperoleh posisi yang baik dalam masyarakat dengan nilai sebesar 71,43 persen.

2. Berdasarkan analisis minat kewirausahaan diketahui bahwa sebanyak 42,86 persen mahasiswa berminat terhadap wirausaha, hal ini menunjukkan minat mereka cukup besar. Sedangkan mahasiswa yang masih dalam pertimbangan dan tidak berminat terhadap kewirausahaan jumlahnya sama yaitu sebesar 28,57 persen, hal ini menunjukkan bahwa ada potensi untuk mengembangkan mahasiswa yang masih dalam pertimbangan ke arah berminat terhadap kewirausahaan.

\section{SARAN}

1. Kepada peneliti yang ingin melakukan penelitian sejenis, sebaiknya ditambahkan variabel lain yang mempengaruhi motivasi kewirausahaan (variabel terikat), misalnya variabel sikap

2. Menggunakan sampel penelitian yang lebih banyak agar hasil yang di harapkan lebih mewakili keadaan penelitian.

3. Mengadakan penelitian lanjutan mengenai strategi pengembangan minat kewirausahaan mahasiswa.

\section{DAFTAR PUSTAKA}

Budiati, Yuli et al. (2012). Minat Mahasiswa Menjadi Wirausaha (Studi Pada Mahasiswa Fakultas Ekonomi Universitas Semarang). Jurnal Dinamika Sosbud. 14(1), 89-100.

Djamarah, Syaiful Bahri. 2011. Psikologi Belajar. Jakarta: Rineka Cipta

Slameto. (2010). Belajar dan Faktor-Faktor yang Mempengaruhinya. Jakarta: PT. Rineka Cipta.

Sugiyono, (2008), Metode Penelitian Kuantitatif Kualitatif dan $R \& D$. Bandung Alfabeta.

Sumardi, K., (2007), Menakar Jiwa wirausaha mahasiswa teknik mesin angkatan 2005. Jurnal Pendidikan Teknologi Kejuruan, IV(10).

Venesaar, Ene. (2006). Students' Attitudes and Intentions toward Entrepreneurship at Tallinn University of Technology. TUTWPE Working Papers. (154), 97-114. 